\title{
Use of multiple regression modeling for the evaluation of lactation characteristics of Awassi sheep
}

\author{
İrfan Güngör ${ }^{1 *}\left(0\right.$, Fatih Atasoy ${ }^{2}(0)$
}

${ }^{1}$ General Directorate of Agricultural Research and Policies, Ankara, Turkey.

${ }^{2}$ Ankara University, Faculty of Veterinary Medicine, Department of Animal Husbandry and Animal Nutrition, Ankara, Turkey.

\section{Article History}

Received: 23 September 2020

Accepted: 13 November 2020

First Online: 25 December 2020

\section{Corresponding Author}

Tel.: +903123157622

Email: irfan.gungor@tarimorman.gov.tr

\section{Keywords}

Awassi sheep

Lactation curve

LEG4

Milk yield

\section{Introduction}

Sheep provide many economically important products, including mutton, milk, and fleece (Güngör and Akçapınar, 2013). In regions with considerable pasture and arid climates, raising sheep is the leading animal husbandry activity (Güngör and Akçapınar, 2013). As of 2019, there were a total of 37.276 .050 head of sheep being raised in Turkey (TUIK, 2019), with Awassi is one of the most widely bred sheep breeds. Awassi is a fattailed species of dairy sheep, named after the tribe of $\mathrm{Al}$ Awas that originates from the area between the Tigris and Euphrates rivers (Epstein, 1982). Awassi are kept in flocks, and raised in large numbers in the Şanlıurfa, Gaziantep, Kilis and Hatay provinces of Turkey and their vicinities, that is to say, in the Southeastern Anatolia region (TAGEM, 2009). They are considered to be superior to other dairy species due to their ability to adapt to different environments and their strong herd instinct (TAGEM, 2009).

Close to 31,473 tonnes of sheep milk is produced in Turkey (TUIK, 2019), being used predominantly in cheese production, and this has led sheep farming to gain importance in recent years (Çoban et al, 2013), resulting in breeding efforts aimed at improving milk yield. Conventional farming methods should be used for efficient production and the full utilization of the flock's potential, with one such method being the use of the lactation curve model within an optimum raising-feeding strategy, depending on the needs and potential of the flock. Using the lactation curve for breeding, flock management and production planning is reported to help increase efficiency in sheep husbandry (Montaldo et al., 1997; Tzouramani et al., 2011; Angeles-Hernandez, 2013). Lactation models have traditionally been developed initially for cattle (Morant and Gnanasakthy, 1989; Beever et al., 1991; Tekerli et al., 2000), while the number of models used for the characterization of the lactation curves of sheep, on the other hand, has been limited (Sakul and Boylan, 1992; Dağ et al., 2005; Keskin and Dağ, 2006).

In lactation curve studies, the goal is to create a lactation curve based on the milk yield of animals milked at different times, and to identify the environmental factors and values that affect the curve. Using the lactation curve, it is possible to understand the effects of such factors as species, lambing year, lambing season, lactation order and age of first lactation on both the lactation 
curve and the total milk yield (Gipson and Grossman, 1990). Lactation curve coefficients are used to examine the effects of the lactation curve on milk production and economic factors (Grossman et al., 1986), determining the shape and the slope of the curve. The sizes of these coefficients, or in other words, the shape of the lactation curve is affected by factors such as the number of births, lambing season, lactation order, age of first lambing, care-feeding, health status and genotype. The effects of these factors can vary by flock or by years, and this is why the parameters of a lactation curve identified for a particular flock can be said to be unique to that flock (Tekerli et al., 2000).

The most well-known lactation curve model still in use is the one proposed by Wood in 1967 (Wood, 1967). The Wood lactation model is used widely in studies examining the factors affecting the lactation curve (YIImaz et al., 2004), while many new models have been proposed since 1967. The Wood lactation model has been used previously in studies of Awassi sheep (Yilmaz et al., 2004). Many parametric models have been developed to characterize lactation curves, including inverse polynomial, gamma type and exponential functions. With the increased use of individual records, more flexible functions for the making of linear predictions have started to be used more frequently (Prakash et al., 2016).

Selection efficiency could be increases through the use of the right lactation curve model, the right milk yield estimate and the right selection of animals, and identifying the lactation curve would help with efficient breeding. This study aims to identify the model with the best fit for the lactation curves of Awassi sheep. The lactation curve was created using the model proposed in this study, and the environmental factors that affect parameters of the lactation curve and OLMY were examined.

\section{Materials and Method}

\section{Animal Material}

The study was conducted between 2013 and 2015 on Awassi sheep at the Şanlıurfa GAP Agricultural Research Institute of the General Directorate of Agricultural Research and Policies of the Ministry of Agriculture and Forestry, making use of the data from 287 sheep (year 2013, n=101; year 2014, $n=82$; year 2015, $n=104$ ) raised within an Awassi sheep breeding project. The lactation milk yields and lactation curves of ewes that lambed in different periods were examined. Lambing started in a different month each year, in November, December and January. The flock was cared for and fed following routine procedures at the Institute. Milk controls were performed on a 24-hour basis, and repeated every 20 days. Milk controls ended when two-thirds of the flock finished lactating, upon which milking was ended for the entire flock. The lactation curve was created based on 1,136 daily milk yield records from 213 ewes. Ewes with fewer than four control milk yields in a lactation period were excluded from the analysis.

\section{Statistical Analysis}

Table 1 presents the lactation models used in the study. The data analysis was carried out using the PROC NLIN option in the SAS (2000) software package. The model with the best fit was identified through a comparison that took into account the correlation coefficient $(r)$, average (residual) error ( $A E)$ and coefficient of determination $\left(R^{2}\right)$. After identifying the model that best characterized the lactation curve, the model parameters were used to calculate estimated lactation milk yields (ELMY).

PROC NLIN procedure:

PROC NLIN; byanim;

MODEL $y=<$ nunlinear model expression $>$;

PARMS $a=<$ değer $>, b=<$ değer $>, c=\ldots ., \ldots, \ldots$;

OUTPUT OUT=<output file name $>$ PREDICTED $=<$ name $>$ RESIDUAL $=<$ residual name $>$

$\mathrm{SSE}=<$ errorsums of square $>\mathrm{PARMS}=\mathrm{a}, \mathrm{b}, \mathrm{c}, \ldots$ (names of model parameterspredicted);

RUN;

To obtain these estimates, daily and total lactation milk yields were calculated for each ewe. The ELMY values obtained using the parameters of the selected model were compared with the OLMY values calculated using the Fleischmann method.

After calculating OLMY and ELMY, SAS PROC CORR was used to calculate the coefficients of the correlation between OLMY and ELMY and the parameters of the model (LEG4).

The model used to examine the environmental factors that affect the observed lactation milk yield (OLMY), the estimated lactation milk yield (ELMY) and the model parameters was as follows: $Y_{i j k}$

$Y_{i j k}=\mu+Y A_{i}+D T_{j}+b\left(X_{i j k}\right)+e_{i j k}$

$Y_{\mathrm{ijk}}$ : ELMY, OLMY, model parameters, $\mu$ : Overall mean in terms of the analyzed trait, $\mathrm{YA}_{\mathrm{i}} \mathrm{i}^{\mathrm{t}^{\text {th }}}$ lambing yearMonth, $\mathrm{DT}_{\mathrm{j}}$ : $\mathrm{j}^{\text {th }}$ birth type, b: the partial regression coefficient of $\mathrm{X}_{\mathrm{ijk}}, \mathrm{X}_{\mathrm{ij \textrm {j }}}$ : lactation lenght of the $\mathrm{k}^{\text {th }}$ ewe, $\mathrm{e}_{\mathrm{ijk}}$ : Residual associated with Yijk

The following model was used to analyze the factors (environmental and flock management) affecting lactation lenght (LD):

$$
Y_{i j k}=\mu+Y A_{i}+D T_{j}+e_{i j k}
$$


$Y_{\mathrm{ijk}}:$ ELMY, OLMY, model parameters, $\mu$ : Overall mean in terms of analyzed trait, $\mathrm{YA}_{i}$ : ith lambing year-Month, $\mathrm{DT}_{\mathrm{j}}$ : jth birth type, $\mathrm{e}_{\mathrm{ijk}}$ : Residual associated with Yijk
The differences between the levels of environmental factors were tested using the LSMEANS/TUKEY option within the PROC GLM system (SAS, 2000).

Table 1. Lactation model

\begin{tabular}{|c|c|c|}
\hline Model Name & Model & Explanation \\
\hline Nelder, 1966 & $y_{t}=t / a+b t+c t^{2}$ & $\begin{array}{l}y_{t}: \text { milk yield (gr / day) at time } t \text { (day) of lactation } \\
a, b, c \text {, and } d \text { are model parameters that determine the shape } \\
\text { and scale of the curve } \\
t \text { : Control interval (days) }\end{array}$ \\
\hline Wood, 1967 & $y_{t}=a t^{b} e^{-c n}$ & $\begin{array}{l}y_{t}: \text { milk yield (gr / day) at time } t \text { (day) of lactation } \\
a, b, c \text {, and d are model parameters that determine the shape } \\
\text { and scale of the curve } \\
t: \text { Control interval (days) }\end{array}$ \\
\hline Morant and Gnanasakthy, 1989 & $y_{t}=\boldsymbol{e}^{\left(a-b t_{1}-c t_{1}^{2}-d / t\right)}$ & $\begin{array}{l}y_{t}: \text { milk yield (gr / day) at time } t \text { (day) of lactation } \\
a, b, c \text {, and d are model parameters that determine the shape } \\
\text { and scale of the curve } \\
t: \text { Control interval (days) }\end{array}$ \\
\hline Cobby and Le Du, 1978 & $y_{t}=a-b t-a e^{-c t}$ & $\begin{array}{l}y_{t}: \text { milk yield (gr / day) at time } t \text { (day) of lactation } \\
a, b, c \text {, and } d \text { are model parameters that determine the shape } \\
\text { and scale of the curve } \\
t \text { : Control interval (days) }\end{array}$ \\
\hline & & $t_{1-}(t-$ Laktasyon usunluğu/2)/100 \\
\hline \multirow{5}{*}{$\begin{array}{l}\text { Legendrepolynomial } \\
\text { Kirkpatrick et al., } \\
\text { 1990; Schaeffer, 2004; } \\
\text { Silvestre et al., 2006; } \\
\text { Koncagül et al., } 2012\end{array}$} & $y_{t}=\sum_{i=1}^{n} \alpha_{i} \Phi(\mathrm{t})$ & $\begin{array}{l}\mathrm{y}_{\mathrm{t}}=\text { milk yield on day } \mathrm{t} \text { control day after birth } \\
\text { the value of } \mathrm{t} \text { varies between }-1 \text { and }+1 \text { (Equation } 1) \\
t=2\left(\frac{t g-t g_{\min }}{t g_{\max }-t g_{\min }}\right)-1 \\
\mathrm{tg}=\text { control day } \\
\mathrm{tg}_{\min }=\text { first control day } \\
\mathrm{tg}_{\max }=\text { last control day }\end{array}$ \\
\hline & \multicolumn{2}{|r|}{$\begin{array}{l}\Phi(t)=\sqrt{\frac{2 n+1}{2}} P_{n}(t) \\
\phi(t)=\text { normalized polynomial } \\
P_{n}(t)=n^{\text {th }} \text { order of the polynomial }\end{array}$} \\
\hline & $P_{2}(t)=\frac{1}{2}\left(3 t^{2}-1\right)$ & LEG2 \\
\hline & $P_{3}(t)=\frac{1}{2}\left(5 t^{3}-3 t\right)$ & LEG3 \\
\hline & $P_{4}(t)=\frac{1}{8}\left(35 t^{4}-30 t^{2}+3\right)$ & LEG4 \\
\hline
\end{tabular}

\section{Results}

Descriptive statistics of the traits are presented in Table 2. A large variation is observed in ewe weight, lactation lenght, lactation milk yield and average daily milk yield. The majority of the flock consisted of young mothers (2, 3 and 4 years old), while there were few older ewes ( 5 years old or above accounted for $12 \%$ of the flock).

Table 3 reports the $r, R^{2}$ and $A E$ values obtained from different models by years. The Cobby and Le Du,
Nelder and Wood models had the lowest performances in terms of $A E$. The rest of the models had $A E$ values that were indistinguishable from zero. The $R^{2}$ values in the Nelder and Cobby and Le Du models were found to be negative. Legendre polynomials (LEG) had the highest $R^{2}$ value. Among the Legendre polynomials, LEG4 had the highest $R^{2}$ value (0.99), followed by LEG3 (0.93) and LEG2 (0.88). The values obtained from the other models were smaller. 
Table 2. Descriptive statistics for the descripted statistics for BW, EW, LD, OLMY and DMY

\begin{tabular}{lccccccc}
\hline Sex & Number (\%) & Age & Number (\%) & & Mean \pm St. Dev & Min. & Max. \\
\hline Male & $147(55,3)$ & 2 & $79(29,7)$ & Birth Weight $(\mathrm{kg})$ & $4.512 \pm 0.737$ & 2.1 & 6.8 \\
Female & $119(44,7)$ & 3 & $79(29,7)$ & Ewe Weight $(\mathrm{kg})$ & $55.848 \pm 7.276$ & 39.2 & 73.4 \\
Type of birth & Number (\%) & 4 & $76(28,6)$ & LD (Days) & $128.643 \pm 29.597$ & 29.0 & 192.0 \\
Single & $205(77,1)$ & 5 & $32(12,0)$ & OLMY (kg) & $105.210 \pm 51.103$ & 26.9 & 288.7 \\
Twins & $61(22,9)$ & Total & $266(100,0)$ & Average Daily Milk Yield (g) & $803.467 \pm 299.493$ & 208.4 & 1874.5 \\
\hline
\end{tabular}

Table 3. Comparison statistics used for the characterization of the lactation curves of Awassi sheep

\begin{tabular}{|c|c|c|c|c|c|}
\hline Year & Model & $\mathbf{n}$ & $r$ & $\mathbf{R}^{2}$ & $\mathrm{AE}$ \\
\hline \multirow{7}{*}{$\stackrel{m}{\stackrel{\sim}{\circ}}$} & Wood & 59 & $0.101 \pm 0.073$ & $0.175 \pm 0.019$ & $621.479 \pm 27.917$ \\
\hline & Nelder & 59 & $0.572 \pm 0.050$ & $-2.190 \pm 0.388$ & $1041.79 \pm 136.669$ \\
\hline & Morant and Gnanastky & 59 & $0.953 \pm 0.010$ & $0.994 \pm 0.001$ & $0.429 \pm 0.314$ \\
\hline & Cobby and Le Du & 59 & $0.577 \pm 0.047$ & $-3.463 \pm 1.773$ & $484.290 \pm 174.501$ \\
\hline & LEG2 & 59 & $0.882 \pm 0.015$ & $0.982 \pm 0.003$ & $0.000 \pm 0.000$ \\
\hline & LEG3 & 59 & $0.937 \pm 0.010$ & $0.992 \pm 0.002$ & $0.000 \pm 0.000$ \\
\hline & LEG4 & 59 & $0.993 \pm 0.004$ & $0.999 \pm 0.000$ & $0.000 \pm 0.000$ \\
\hline \multirow{7}{*}{ 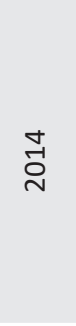 } & Wood & 66 & $-0.203 \pm 0.051$ & $0.166 \pm 0.013$ & $623.123 \pm 29.732$ \\
\hline & Nelder & 66 & $0.499 \pm 0.059$ & $-2.511 \pm 0.449$ & $1032.079 \pm 136.314$ \\
\hline & Morant and Gnanastky & 66 & $0.896 \pm 0.020$ & $0.983 \pm 0.004$ & $-0.666 \pm 0.608$ \\
\hline & Cobby and Le Du & 66 & $0.299 \pm 0.055$ & $-18.576 \pm 4.154$ & $1674.951 \pm 265.660$ \\
\hline & LEG2 & 66 & $0.819 \pm 0.023$ & $0.966 \pm 0.005$ & $0.000 \pm 0.000$ \\
\hline & LEG3 & 66 & $0.908 \pm 0.020$ & $0.985 \pm 0.003$ & $0.000 \pm 0.000$ \\
\hline & LEG4 & 66 & $0.969 \pm 0.012$ & $0.998 \pm 0.001$ & $0.000 \pm 0.000$ \\
\hline \multirow{7}{*}{ 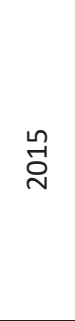 } & Wood & 88 & $-0.424 \pm 0.048$ & $0.089 \pm 0.011$ & $816.425 \pm 31.741$ \\
\hline & Nelder & 88 & $0.454 \pm 0.047$ & $-1.100 \pm 0.249$ & $934.978 \pm 120.506$ \\
\hline & Morant and Gnanastky & 88 & $0.914 \pm 0.011$ & $0.985 \pm 0.002$ & $1.207 \pm 1.462$ \\
\hline & Cobby and Le Du & 88 & $0.117 \pm 0.048$ & $-32.816 \pm 3.742$ & $3805.829 \pm 269.271$ \\
\hline & LEG2 & 88 & $0.84 \pm 0.0170$ & $0.975 \pm 0.003$ & $0.000 \pm 0.000$ \\
\hline & LEG3 & 88 & $0.910 \pm 0.012$ & $0.986 \pm 0.002$ & $0.000 \pm 0.000$ \\
\hline & LEG4 & 88 & $0.958 \pm 0.007$ & $0.993 \pm 0.001$ & $0.000 \pm 0.000$ \\
\hline
\end{tabular}

The LEG4 model performed better than the other models in its characterization of the lactation curves of Awassi sheep. The comparison criteria for the model selection included the coefficient of correlation ( $r$ ) between the observed and estimated lactation curves, the average error $(\mathrm{AE})$ and the coefficient of determination $\left(R^{2}\right)$. The models of Cobby and Le Du, Nelder and Wood had the lowest performance in terms of $A E$, while the remaining models had $A E$ values that were indistinguishable from zero. The values obtained from the other models were smaller. Taking $\mathrm{HO}, \mathrm{R}^{2}$ and $r$ parameters together, LEG4 was found to best characterize the lactation curves of the Awassi sheep used in the study. In light of these findings, LEG4 was selected as the evaluation model for the study for the identification of features of the lactation curve, as well as the environmental factors affecting the lactation curve and OLMY. Table 4 presents the least square means of the OLMY, LD and model parameters.

The present study also compares the conventional models widely used in lactation curve studies with more recent models. Milk controls were carried out every 20 days to reduce error and to allow a more accurate calculation of OLMY, and the observed and estimated milk yields were found to be very close to one another. Lambings started in different months, as in 2013, when the project began, the flock was brought together from different farmers. Despite all of these issues, OLMY and ELMY overlapped to a significant extent. A rapid decline was noted following the peak in the lactation curve of ewes who lambed in 2015, apart from irregularities in peak levels observed for other years as well, a decline that can be attributed to the harsh winter conditions following lambing in 2015, and the replacement of shepherds. 
Table 4. Least square means of model parameters and observed (OLMY) and estimated (ELMY) lactation milk yields by years

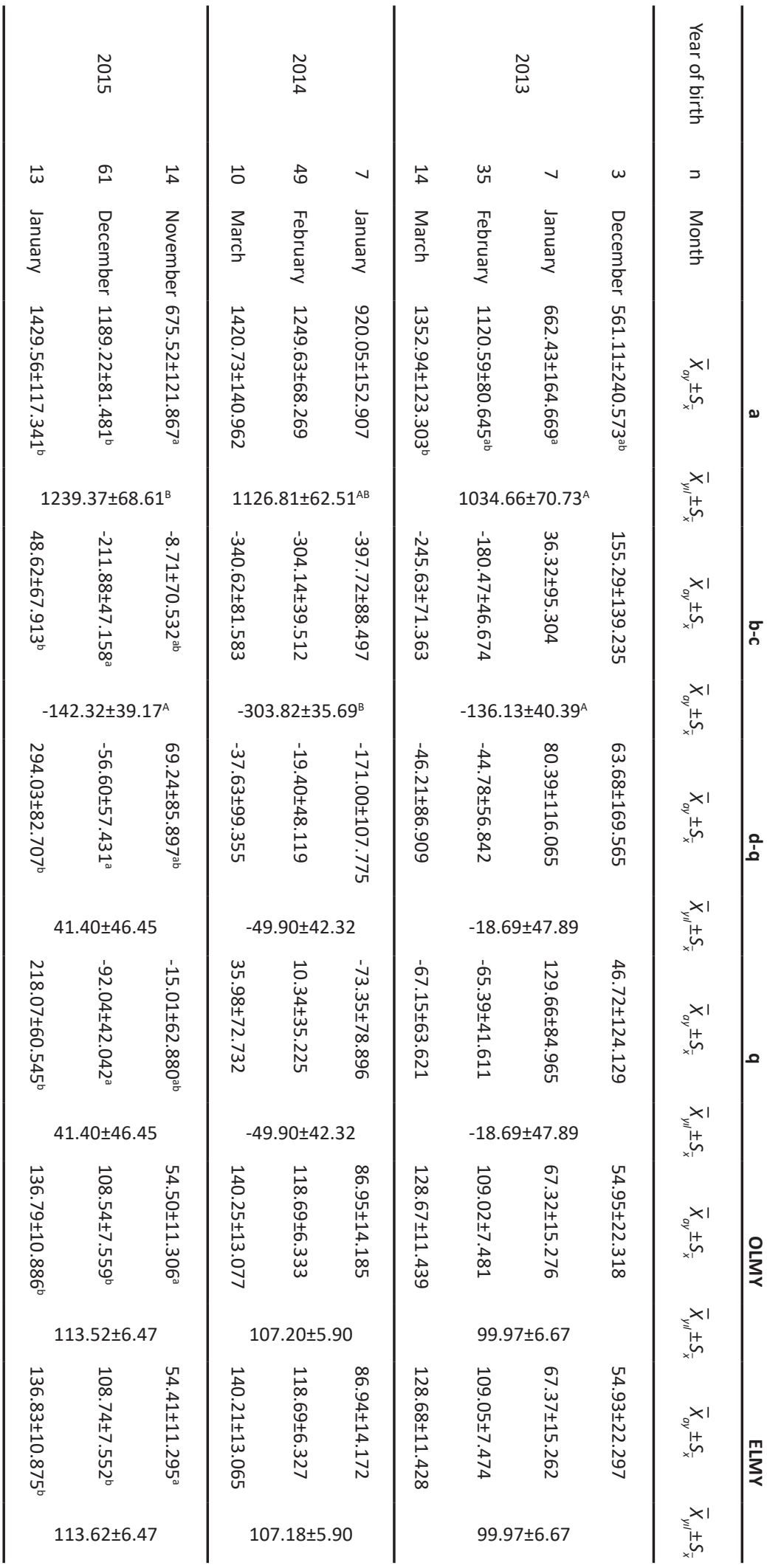




\section{Description of Model Parameters}

Parameters representing changes in the lactation curve.

- Parameter $a$ : the estimated daily milk yield in the middle of lactation, the milk yield when corrected time is zero.

- Parameters b-c: the ups and downs in milk yield in the first half of the lactation period.

- Parameters $\mathrm{d}-\mathrm{q}$ : the ups and downs in the second half of the lactation period (Silvestre et al., 2006; Koncagül et al., 2012).

\section{Effects of Environmental Factors}

The environmental factors that affect the lactation parameters, year and month of birth, type of birth, and OLMY and ELMY effects, were examined. The effects of birth year and month on parameter $\boldsymbol{a}$ (milk yield in the middle of the lactation period) varied by year, with parameter $\boldsymbol{a}$ being observed to increase significantly $(P<0.05)$ with births taking place in later months and over the years. In terms of the effects on parameters $\boldsymbol{b}$ - $\boldsymbol{c}$, which represent the fluctuations in milk yield from the beginning to the middle of the lactation period, and parameters $\boldsymbol{d}-\boldsymbol{q}$, representing the fluctuations in the second half of the lactation period, the year of birth was found to have a significant effect on parameters $\boldsymbol{b}$ - $\boldsymbol{c}$ only $(P<0.05)$. In general, there was an increase in OLMY and ELMY in later birth months and years, although the only significant differences were those between the all months of $2015(P<0.05)$. The ewes who started lactating in later months were observed to have higher OLMY values than those who started in earlier months. This can be attributed to conditions in the Şanlıurfa province, where, despite some year-to-year fluctuations, the pasture conditions improve with spring, meaning that ewes that started lactating close to the beginning of spring were exposed to better pasture conditions between birth and peak yield.

\section{Relationships Between Parameters}

Table 5 reports the correlations between model parameters. In terms of model parameters the highest correlation ( $r=0.843$ ) was observed between $d$ and $q$, followed by those between $c-d$ and $b-q$. The relationship between OLMY and ELMY was found to be very strong ( $r=0.999)$. Parameter $a$ was also found to have a very strong relationship with OLMY and ELMY. A breeding program based on parameter $\boldsymbol{a}$ would likely improve the trait of OLMY.

The observed and estimated overall lactation curves similar classical lactation curve and display a regular increase and decrease (Figure1). The observed and estimated lactation milk yields overlapped to a significant extent.

Table 5. Coefficients of correlation between model parameters of the LEG4 function, OLMY, ELMY and LD.

\begin{tabular}{lccccccc}
\hline & $\mathbf{b}$ & $\mathbf{c}$ & $\mathbf{d}$ & $\mathbf{q}$ & LSV & TLSV & LS \\
\hline $\mathrm{a}$ & 0.026 & $-0.248^{* *}$ & 0.019 & -0.026 & $0.911^{* *}$ & $0.911^{* *}$ & $0.300^{* *}$ \\
$\mathrm{~b}$ & & $0.450^{* *}$ & $0.531^{* *}$ & $0.619^{* *}$ & -0.055 & -0.055 & 0.105 \\
$\mathrm{c}$ & & & $0.769 * *$ & $0.600^{* *}$ & $-0.332^{* *}$ & $-0.332^{* *}$ & $-0.215^{* *}$ \\
$\mathrm{~d}$ & & & & $0.843^{* *}$ & -0.074 & -0.074 & 0.007 \\
q & & & & & -0.116 & -0.116 & -0.066 \\
LSV & & & & & & $0.999 * *$ & $0.606 * *$ \\
TLSV & & & & & & & $0.607 * *$ \\
\hline
\end{tabular}

${ }^{*} \mathrm{P}<0.05,{ }^{* *} \mathrm{P}<0.01, \mathrm{a}, \mathrm{b}, \mathrm{c}, \mathrm{d}$, q: Fourth order Legendre polynomial model parameters, OLMY: Observed lactation milk yield, ELMY: Estimated lactation milk yield based on model parameters, LD: Lactation length.

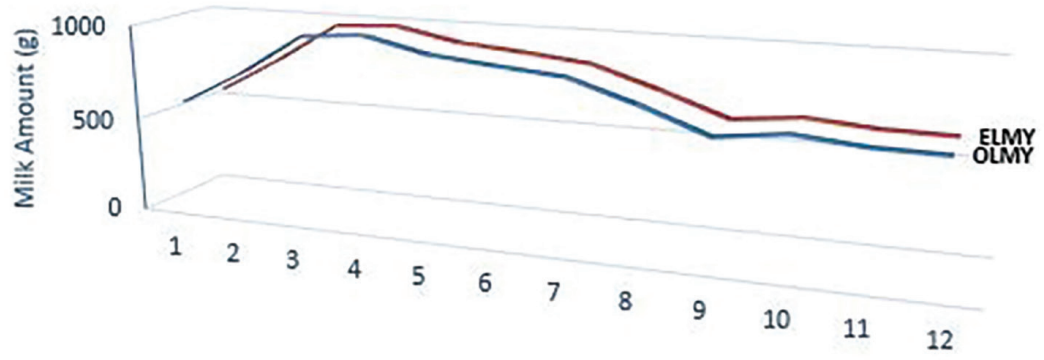

Milk Measurement Order

Figure 1. Observed and estimated lactation curve. 


\section{Discussion}

The lactation curves of ewes have been studied by many researchers, but have usually been based on only partial lactation data, as the general practice in sheep husbandry is to focus on milk yield records after the weaning of lambs. This corresponds to a period after peak yield, which makes it impossible to estimate the shape of the curve from the beginning of lactation up until peak yield (Pollott and Gootwine, 2000). Lactation following peak yield usually follows a linear trajectory, which can be characterized by simple linear models. The total lactation milk yields in the present study were observed to be similar to those reported by previous studies of Awassi sheep (Seker et al., 2000; Dağ et al., 2005; Tekel et al., 2007). On the other hand, OLMY and ELMY values were found to be lower than those reported by Gootwine and Pollott (2000). Moreover, the obtained lactation curves were found to be consistent with the lactation curve given by Kaymakçı (2006). OLMY increased in the two months following lambing to reach peak yield, after which it followed a declining trajectory.

In the present study, LEG4 was found to be the model that best characterized the lactation curves of Awassi sheep kept under Institute conditions in Şanlıurfa. Ruiz et al. (2000) argue that a high positive correlation among the model parameters used to characterize lactation curves would prevent the accurate characterization of the lactation curve. However, the observed lactation curves and the lactation curves estimated using the LEG4 model in the present study overlapped to a significant extent, despite the strong and positive correlation among the model parameters, indicating that Ruiz et al.'s (2006) argument does not always apply. Moreover, the highest correlations between OLMY and ELMY in years 2013, 2014, and 2015 were 0.993, 0.969, and 0.958 , respectively, indicating that the LEG4 model used in the present study was successful in characterizing the lactation curves.

Birth month was found to have a significant effect $(P<0.05)$ on OLMY in 2015 , and this finding is consistent with other studies examining the effects of environmental factors on lactation milk yields in Awassi sheep (Ozbey and Akcan, 2000; Reiad et al., 2010). Total milk yield is closely related to the genotype of sheep and the environmental conditions under which they are kept, in addition to other quantitative factors. The fit of lactation curve models used by different researchers naturally varies depending on the species and breed of the sheep. Elvira et al. (2013) report that the lactation curves of Lacuna sheep are best characterized by the Pollat Additive and Fractional models, while Ünal et al. (2007) found the Wilmink, Wood and Dhanoa models to be more successful in characterizing the lactation curves of Ak- karaman sheep, as well as Kıvırcık-Akkaraman and SakızAkkaraman crossbreds. Regarding the characterization of the lactation curves of Awassi sheep, on the other hand, Dağ et al. (2005) recommend the Cubic model, whereas Yıldız (1997) reported Wood to be the best model, with the Cobby and LeDu, Dhanoa and Wilming models performing equally well. In a study comparing three different lactation models, Çoban and Kayaalp (2013) reported similar results. In a study comparing linear and non-linear models, Pollott and Gootwine (2000) reported similar findings. Findings are similar to those reported by Esenbuğa and Bilgin (2004) in their study on the lactation curves of Awassi sheep. The model identified as the best performer in characterizing the lactation curve can be used to identify ewes with low yields and remove them from the flock. This would have a direct effect on profitability and efficiency. The LEG4 model used in the present study was found to perform better than the other models. The ELMY estimated using the LEG4 model was found to be very close $(0.958<r<0.993)$ to the OLMY calculated using the Flesichmann method. The LEG4 model can be used to predict the lactation milk yields of Awassi sheep kept under conditions similar to those prevailing in the Şanlıurfa province of Turkey.

\section{Conclusion}

Despite the widespread practice in Şanlıurfa of using November and December as the lambing period, it would be better, in terms of total lactation yield, to have the lambings in January and February. It was also found that twin births were no different in terms of milk yield when compared to single births, and farmers in the region usually prefer single births.

The milk yields of Awassi sheep were found, as expected, to be high, and the findings of the present study suggest that it is possible to improve yields of even further through breeding. The findings of the present study can be expected to provide guidance in future breeding efforts with the goal of increasing milk yields. When the $\mathrm{HO}, \mathrm{R}^{2}$ and $r$ parameters were considered together, the fourth-order Legendre polynomial (LEG4) model was found to best predict the lactation curves of Awassi sheep. This study is expected to make a significant contribution to the literature through its examination of regression models in detail, to apply these models to the Awassi dairy species and interpret the results, and to provide future researchers with valuable information.

\section{Acknowledgements}

This study is a summary of the first author's PhD thesis. The data were obtained from Şanlıurfa GAP Agricultural Research Institute of the General Directorate of Agricultural Research and Policies of the Ministry of Agriculture and Forestry making use. Project No: TA- 
GEM/11/08/01/01. Restrictions apply to the availability of these data, which were used with permission for this study. The authors are thankful to, The General Directorate of Agricultural Research and Policies (GDARP) and Şanlıurfa GAP Agricultural Research Institute, to provide the necessary animal material to carry out the research program.

\section{References}

Beever, D. E., Rook, A. J., France, J., Dhanoa, M. S., \& Gill, M. (1991). A review of empirical and mechanistic model of lactation performance by the dairy cow. Livestock Production Science, 29, 115130. https://doi.org/10.1016/0301-6226(91)90061-T

Cobby, J. M., \& Le Du, Y. L. P. (1978). On fitting curves to lactation data. Animal Science, 26(2), 127-133. https://doi.org/10.1017/ S0003356100039532

Çoban, F., \& Kayaalp, G. T. (2013). Süt Koyunculuğunda Laktasyon Eğrisi Modellerinin Karşılaştırmalı Olarak İncelenmesi [ Comparative Analysis of Lactation Curve Models in Dairy Sheep Farming]. Çukurova Üniversitesi Fen ve Mühendislik Bilimleri Dergisi, 29(1), 80-88.

Dağ, B., Keskin, I., \& Mikailsoy, F. (2005). Application of different model to the lactation curves of unimproved Awassi Ewes in Turkey. The South African Journal of Animal Science, 35(4), 238-243.

Elvira, L., Hernandez, F., Cuesta, P., Cano, S., Gonzalez-Martin, J., \& Astiz, S. (2013). Factors affecting the lactation curves of intensively managed sheep based on a clustering approach. Journal of Dairy Research, 80(4), 439-447. https://doi.org/10.1017/ S0022029913000381

Epstein, H. (1982). Awassi Sheep, World Animal Review, Editor, D.E. Faulkner. FAO.

Esenbuğa, N., \& Bilgin, Ö. C. (2004). İvesi koyunlarının laktasyon eğrisinin tahmini ve tanımlanması için farklı matematik modellerin mukayesesi [Comparison of different mathematical models for estimation and definition of the lactation curve of Ivesi sheep]. Ulusal Zootekni Bilim Kongresi, 166 - 169. 1-3 Eylül 2004. Süleyman Demirel Üniversitesi.

Gipson, T. A., \& Grossman, M. (1990). Lactation curves in dairy goats: A review. Small Ruminant Research, 3, 383-396.

Gootwine, E., \& Pollott, G. E. (2000). Factor saffecting milk production in Improved Awassi dairy ewes. Animal Science, 71, 607-615.

Grossman, M., Kuck, A. L., \& Norton, H. W. (1986). Lactation Curves of Pure bred and Cross bred Dairy Cattle. Journal of Dairy Science, 69, 195-203.

Güngör, I., \& Akçapınar, H. (2013). The Production Traits of Bafra Sheep Reared in Ankara Conditions. Livestock Studies, 53-2, 059-073.

Keskin, I., \& Dağ, B. (2000). Comparison of different mathematical models for describing the complete lactation of akkaraman ewes in Turkey. Asian-Australasian Journal of Animal Sciences, 19, 1551-1555.

Kirkpatrick, M., Lofsvold, D., \& Bulmer, M. (1990). Analysis of the inheritance, selection and evolution of grow thtrajectories. Genetics, 124, 979-93.

Koncagül, S., Daşkıran, I., \& Bingöl, M. (2012). Yetiştirici Elinde Bulunan Norduz Koyunlarının Laktasyon Süt Verimi ve Laktasyon Eğrisine Etki Eden Faktörler [Lactation Milk Yield and Factors Affecting the Lactation Curve of Norduz Sheep Breeders]. Kafkas Universitesi Veteriner Fakültesi Dergisi, 18(4), 677-684.

Morant, S. V., \& Gnanasakthy, A. (1989). A new approach to the mathematical formulation of lactation curves. Animal Science, 49, 151162.
Nelder, J. A. (1966). Inverse Polynomials. A Useful Group of Multi-factor Response Functions. Bio-metrics, 22, 128-144.

Ozbey, O., \& Akcan, A. (2000). Production performance of Akkaraman, Morkaman and Awasi sheep under semi-intensive conditions I. Fertility and milk production characteristics. Veteriner Bilimleri Dergisi, 16(1), 109-120.

Pollott, G. E., \& Gootwine, E. (2000). Appropriate mathematical models for describing the complete lactation of dairy sheep. Animal Science, 71, 197-207.

Prakash, V., Gupta, A. K., Gupta, A., \& Gandhi, R. S. (2016). Lactation curve modeling using Legendre Polynomial in Sahiwal cattle. The Indian Journal of Animal Sciences, 86(4), 485-488.

Reiad, K., Al-Azzawi, W., Al-Najjar, K., Masri, Y., Salhab, S., Abdo, Z., El-Herek, I., Omed, H., \& Saatci, M. (2010). Factor influencing the milk production of Awassi sheep in a flock with theve selected lines at the Agricultural Scientific Research Center in Salamieh-Syria. Kafkas Universitesi Veteriner Fakultesi Dergisi, 16(3), 425-430.

Ruiz, R., Oregui, L. M., \& Herrerot, M. (2000). Comparison of models for describing the lactation curve of latxa sheep and an analysis of factors affecting milk yield. Journal of Dairy Science, 83, 27092719.

Sakul, H., \& Boylan, W. J. (1992). Lactation curves for several US sheep breeds. Animal Production Science, 54, 229-233.

SAS. (2000). SAS/STAT. SAS Inst Inc, Cary, NC, USA.

Schaeffer, L. R. (2004). Application of random regression models in animal breeding. Livestock Production Science, 86, 35-45.

Seker, I., Kul, S., \& Bayraktar, M. (2000). Linear udder traits and relationships between these and milk yield in Awassi and East-Friesian $x$ Awassi crossbreed $\left(F_{1}\right)$ ewes. Lalahan Hayvancilık Araştırma Enstitüsü Dergisi, 40(2), 45-55.

Silvestre, A. M., Petim-Batista, F., \& Colaço, J. (2006). The accuracy of seven mathematical functions in modeling dairy cattle lactation curves based on test-day records from varying sample schemes. Journal of Dairy Science, 89, 1813-1821.

TAGEM. (2009). Türkiye Evcil Hayvan Genetik Kaynakları Kataloğu [Turkey Domestic Animal Genetic Resources Catalog]. T.C. Tarım ve Köyişleri Bakanlı̆̆ı, Tarımsal Araştırmalar Genel Müdürlüğü, 34-35.

Tekel, N., Sireli, H. D., \& Elicin, M. A. (2007). Research on the repeatability of milk yield in Awassi sheep. Harran Üniversitesi Ziraat Fakültesi Dergisi, 11(1/2)49-53.

Tekerli, M., Akinci, Z., Dogan, I., \& Akcan, A. (2000). Factors Affecting the Shape of Lactation Curves of Holstein Cows from the Balikesir Province of Turkey. Journal of Dairy Science, 83, 1381-1386.

TUIK. (2019). Animal Production Statistics. Ankara, Turkey. TUIK.

Tzouramani, I., Sıntorı, A., Lıontakıs, A., Karanikolas, P., \& Alexopoulos, G. (2011). An assessment of the economic performance of organic dairy sheep farming in Greece. Livestock Science, 141, 136-142.

Ünal, N., Orman, M. N., Çolak, C., Atasoy, F., Mundan, D., \& Aytac, M. (2000). Comparision of various models for lactation curves of Akkaraman and its crossbreds (Chios x Akkaraman F1 and Kivircık $x$ Akkaraman F1) ewes. Lalahan Hayvancilık Araştırma Enstitüsü Dergisi, 47(2), 7-13.

Wood, P. D. P. (1967). Algebraic model of the lactation curve in cattle. Nature, 216, 164-165

Yıldız, A. (1997). Lactation curve of Awassi sheep and affecting factors in the State of Ceylanpınar Farm. Ph.D. Thesis, Fırat Üniversitesi Sağlık Bilimleri Enstüsü Elazığ.

Yılmaz, O., Denk, H., \& Nursoy, H. (2004). Milk yield characteristics of Norduz sheep. Van Veterinary Journal, 15(1-2), 27-31. 